\title{
Physical education teachers; physical activity level and affecting factors (the example of Çanakkale)
}

\author{
Omer DURUKAN ${ }^{1}$, Gulsah SAHIN ${ }^{2}$, Haydar DURUKAN ${ }^{3}$ \\ ${ }^{1}$ Biga Bakacak Secondary School, Çanakkale, Turkey. \\ ${ }^{2}$ Department of Training Education, School of Physical Education and Sport, Çanakkale Onsekiz Mart University, Çanakkale, Turkey \\ ${ }^{3}$ Department of Elemantary Teacher Education, Faculty of Education, Çanakkale Onsekiz Mart University, Çanakkale, Turkey. \\ Address Correspondence to G. Sahin, e-mail; nazgulsah@hotmail.com
}

\begin{abstract}
The purpose of this research is to investigate the relationship between the physical activity levels of physical education teachers working in schools in Canakkale town and counties and gender, age, years of service, marital status and region of residence. A total of 124 physical education teachers working in schools linked to the Ministry of National Education in the teaching year 2012-2013 participated in the study. To determine variables such as gender, age, height, weight, marital status, years of service and area of residence, the researchers developed a data collection form. To determine levels of physical activity, the long form of the international physical activity questionnaire (IPAQ) was used. The work activity levels and total activity levels were calculated according to the gender, age, years of service, marital status and area of residence of the physical education teachers. For differential analysis of variables, the non-parametric Mann Whitney U test and Kruskall Wallis test were used. While there was no significant difference found between the physical activity levels of physical education teachers and gender, age and years of service ( $>0.05)$, there was a significant difference according to area of residence $(p<0.05)$. The physical activity level of physical education teachers is affected by the area they live in. Teachers living close to Canakkale provincial town or in areas with high socio-economic levels were found to have higher levels of physical activity.
\end{abstract}

Keywords: Exercise, IPAQ, physical activity levels, physical education teachers.

\section{INTRODUCTION}

The living conditions of this age have led to people moving less and less. According to the 2002 World Health Organization (WHO) report, lack of movement causes the deaths of 1.9 million people around the world each year. Physical activity, defined as activity using muscle and joints in daily life to expend energy, increase heart and respiration rates and resulting in tiredness of different intensities, improves physiological, metabolic and psychological parameters, reduces risks of many chronic diseases and early mortality, and helps to maintain the health of bones and muscles (14). Increased standards of living, the intensely competitive environment of professional life and problems related to stress have increased people's physical and social needs.

Occupation, or working life, is one of the most central areas of human life as a social activity maintaining the continuation of life extending back to the birth of humanity. However, most individuals are unable to fulfill this need before problems due to working life appear (2). Additionally apart from working life, doing regular physical activity and participating in physical activity while also helping individuals to avoid various diseases, allows us to preserve increases in physical capacity of healthy individuals, and be more productive in our work performance, household activities and recreation. The positive contribution to daily productivity of increasing physical capacity and feelings of selfconfidence are a natural result of this participation. By the nature of their branch, physical education teachers are required to use many methods and physical applications in their lesson plans. In this situation, teachers need to be able, both physically and pedagogically; to produce lessons with rich contents, different activities and organize events that motivate students and this requires a certain level of being active. A variety of studies have shown that physical education teachers use teaching methods and contents that are no longer used, however they emphasize that currently physical education 
teachers are responsible in terms of following newly-developing methods and contents and in increasing knowledge and levels of physical activity (18).

The hypothesis of this research is that physical education teachers are physically active and that this activity level is affected by different situations such as years of service, marital status, gender, age and place of residence. It is expected that the physical activity levels of physical education teachers will be better due to occupational characteristics and it is considered that it is necessary to investigate which factors change this situation most.

The aim of this research is to investigate the relationship between the physical activity levels of physical education teachers working in schools in Canakkale central town and counties and gender, age, years of service, marital status and region of residence.

\section{MATERIAL \& METHODS}

\section{Subjects}

A survey model was used. The population of the research comprised 175 physical education teachers working in schools linked to the Ministry of National Education in Canakkale central town and villages in 2012-2013. The study group used a cluster sampling technique to represent the population. A random method was used to create the clusters and select the participants. Sampling, not including the counties of Bozcaada and Gokceada due to the small number of teachers in these areas, took account of the geographical location and socio-economic development of other counties and initially divided them into 5 groups, then chose one county in each of these groups to select the 124 physical education teachers. To ensure the sufficiency of the sample to represent the total population, it was concluded that the sample needed to comprise 124 physical education teachers according to $95 \%$ confidence interval and $0.05 \%$ error.

\section{Data collection instruments}

To determine variables such as gender, age, height, weight, marital status, years of service and area of residence the researchers developed a data collection form. To determine levels of physical activity the long form of the international physical activity questionnaire (IPAQ) was used comprising 27 questions (8). The validity and reliability studies of the Turkish version of the questionnaire were completed by Öztürk (16) and Sağlam et al. (17). The long form IPAQ includes duration (minutes) and frequency (days) for all types of activities in all areas for total score calculation.

In this study the long version of IPAQ, with the 'last 7 days' reference period, was used. The long version of IPAQ assesses total physical activity level and it separates physical activity levels in four domains (work, transport, domestic \& garden, and leisure-time) and sedentary time. The long version of IPAQ estimates energy expenditure for 11 separate activity categories: 1) walking at work, 2) moderate intensity physical activity at work, 3) vigorous intensity physical activity at work, 4) walking for transportation, 5) cycling for transportation, 6) moderate-intensity garden/yard chores, 7) vigorous intensity garden/yard chores, 8) moderate-intensity inside chores, 9) walking in leisure time, 10) moderate-intensity leisure-time physical activity, and 11) vigorous-intensity leisuretime physical activity. Energy expenditure in a specific activity category (e.g. moderate-intensity leisure-time physical activity) was calculated by multiplying weekly frequency, usual duration and metabolic equivalent of the respective activity category and sitting score as hour per week (hour/week). Physical activity scores computed for different categories are summed up to estimate the energy expenditure within the specific domain. The sum of different intensity physical activities in the specific domain represents the total physical activity for that domain (e.g. the sum of energy expended in walking at work, moderate-intensity physical activity at work, and vigorous-intensity physical activity at work represents the total physical activity score in work domain). The sum of the scores for specific intensity activities across different domains represents the total intensity-specific physical activity score (e.g. the sum of energy expended in vigorous-intensity activity at work and vigorous intensity leisure-time activity represents the total vigorous-intensity physical activity score). The sum of the physical activity scores in all categories, i.e. in all domains, represents the estimation of the total physical activity (IPAQ) (22). In calculating the questionnaire, sitting points and weekend activity levels were not considered. This research used special calculations according to area of interest. Evaluation according to work activity points and total general activity points from the questionnaire was completed and is presented. 


\section{Procedure}

The application of the questionnaire was completed face-to-face by reaching physical education teachers in villages, counties and the central town and explaining the questionnaire. All procedure was approved by Canakkale Onsekiz Mart University, Medical Faculty, Clinical Research Ethics Committee Chair (Date: 31.01.2013, Number 050.99-50). To complete the survey permission was obtained from Canakkale Provincial National Education Directorate (date: 25.02.2013, Number: 60305806-044-02988).

\section{Statistical Analysis}

For the analysis of data the SPSS 21.0 program was used. Each item was coded and entered, and then the data were prepared for analysis using the data screening technique. Normality of distribution related to dependent variables was examined and skewness and kurtosis values were examined with histogram analysis and it was assumed that distribution was not normal. The skewness and kurtosis values were not between -1 and +1 and as a result of failure to observe skewed graphical curves distant from the zero value on histogram analysis, it was accepted that the distribution was not normal. For differential analysis of variables, the nonparametric Mann Whitney $U$ test and Kruskall Wallis test were used. Significance was taken as 0.05 . To determine which two groups produced significant differences related to the Kruskall Wallis test and to interpret the Mann Whitney $U$ test, the Bonferroni correction was applied and the current level of significance was divided by the group number to recalculate the significance level of the $p$ value. Pairwise comparisons were interpreted using this value for significance level.

\section{RESULTS}

The study sample participants comprised $29 \%$ female teachers and $71 \%$ male teachers. Of the teachers $5.6 \%$ were in the age range 21-25 years, $8.1 \%$ were between $26-30$ years, $15.3 \%$ were between 31-35 years, $29.8 \%$ were between $36-40$ years and $41.2 \%$ were in the age range above 41 years.

Table 1. Descriptive statistics of the sample group

\begin{tabular}{llcc}
\hline Independent Variables & & $\mathrm{n}$ & $\%$ \\
\hline \multirow{2}{*}{ Gender } & Female & 36 & 29.0 \\
& Male & 88 & 71.0 \\
& Total & 124 & 100.0 \\
Height $(\mathrm{cm})$ & $150-159$ & 3 & 2.4 \\
& $160-169$ & 31 & 25.0 \\
& $170-179$ & 53 & 42.7 \\
& $180-189$ & 33 & 26.7 \\
& 190 and above & 4 & 3.2 \\
& Total & 124 & 100.0 \\
Weight $(\mathrm{kg})$ & $50-59$ & 16 & 12.9 \\
& $60-69$ & 23 & 18.5 \\
& $70-79$ & 29 & 23.4 \\
& $80-89$ & 36 & 29.1 \\
& $90-99$ & 15 & 12.1 \\
& 100 and above & 5 & 4.0 \\
& Total & 124 & 100.0 \\
& & &
\end{tabular}

When the marital status of teachers is examined, $79 \%$ were married and $21 \%$ were single. According to length of service $13.7 \%$ had worked for between 1-5 years, $11.3 \%$ had worked from 6-10 years, $25.8 \%$ had worked from 11-15 years, $20.2 \%$ had worked from 16-20 years, $15.3 \%$ had worked from $21-25$ years and $13.7 \%$ had worked for more than 26 years. When the place of residence of teachers is investigated, $42.7 \%$ lived in Canakkale center, $26.6 \%$ lived in Biga, $8.9 \%$ lived in Ezine, $13.7 \%$ lived in Gelibolu and $8.1 \%$ lived in Yenice.

Table 2. Distribution and difference according to gender and marital status

\begin{tabular}{|c|c|c|c|c|c|}
\hline Dependent Variables & & Mean Square & Sum of Squares & $\mathrm{z}$ & $\mathrm{p}$ \\
\hline \multicolumn{6}{|l|}{ Gender } \\
\hline \multirow[t]{3}{*}{ Work Activity Levels } & Female & 63.51 & 2286.50 & & \\
\hline & Male & 62.09 & 5463.50 & -0.201 & 0.840 \\
\hline & Total & 124 & & & \\
\hline \multirow[t]{3}{*}{ Total Activity Levels } & Female & 62.35 & 2244.50 & & \\
\hline & Male & 62.56 & 5505.50 & -0.030 & 0.976 \\
\hline & Total & 124 & & & \\
\hline \multicolumn{6}{|l|}{ Marital Status } \\
\hline \multirow[t]{3}{*}{ Work Activity Levels } & Married & 61.83 & 6059.00 & & \\
\hline & Single & 65.04 & 1691.00 & -0.406 & 0.685 \\
\hline & Total & & & & \\
\hline \multirow[t]{3}{*}{ Total Activity Levels } & Married & 63.37 & 6210.00 & & \\
\hline & Single & 59.23 & 1540.00 & -0.522 & 0.602 \\
\hline & Total & & & & \\
\hline
\end{tabular}


Table 3. Distribution and difference according to age and place of residence

\begin{tabular}{|c|c|c|c|c|c|}
\hline Dependent Variables & & $\mathrm{N}$ & Mean square & $x^{2}$ & $\mathrm{p}$ \\
\hline \multicolumn{6}{|l|}{ Age } \\
\hline \multirow[t]{6}{*}{ Work Activity Levels } & $21-25$ & 7 & 49.07 & 2.112 & 0.715 \\
\hline & $26-30$ & 10 & 59.70 & & \\
\hline & $31-35$ & 19 & 57.39 & & \\
\hline & $36-40$ & 37 & 62.69 & & \\
\hline & 41 years and above & 51 & 66.66 & & \\
\hline & Total & 124 & & & \\
\hline \multirow[t]{6}{*}{ Total Activity Levels } & $21-25$ & 7 & 38.14 & 8.285 & 0.082 \\
\hline & $26-30$ & 10 & 46.90 & & \\
\hline & $31-35$ & 19 & 61.11 & & \\
\hline & $36-40$ & 37 & 60.05 & & \\
\hline & 41 years and above & 51 & 71.20 & & \\
\hline & Total & 124 & & & \\
\hline \multicolumn{6}{|l|}{ Duration of Service } \\
\hline \multirow[t]{7}{*}{ Work Activity Levels } & $1-5$ & 17 & 53.26 & 2.169 & 0.825 \\
\hline & $6-10$ & 14 & 58.21 & & \\
\hline & $11-15$ & 32 & 62.83 & & \\
\hline & $16-20$ & 25 & 63.26 & & \\
\hline & 21-25 & 19 & 66.21 & & \\
\hline & 26 and above & 17 & 69.38 & & \\
\hline & Total & 124 & & & \\
\hline \multirow[t]{7}{*}{ Total Activity Levels } & $1-5$ & 17 & 43.47 & 7.651 & 0.177 \\
\hline & $6-10$ & 14 & 63.50 & & \\
\hline & $11-15$ & 32 & 59.66 & & \\
\hline & $16-20$ & 25 & 66.38 & & \\
\hline & 21-25 & 19 & 67.34 & & \\
\hline & 26 and above & 17 & 74.94 & & \\
\hline & Total & 124 & & & \\
\hline \multicolumn{6}{|l|}{ Place of Residence } \\
\hline \multirow[t]{6}{*}{ Work Activity Levels } & Center & 53 & 71.92 & 10.497 & $0.033^{*}$ \\
\hline & Biga & 33 & 55.73 & & \\
\hline & Ezine & 11 & 62.91 & & \\
\hline & Gelibolu & 17 & 61.91 & & \\
\hline & Yenice & 10 & 35.50 & & \\
\hline & Total & 124 & & & \\
\hline \multirow[t]{6}{*}{ Total Activity Levels } & Center & 53 & 72.92 & 26.327 & $0.000^{* *}$ \\
\hline & Biga & 33 & 51.45 & & \\
\hline & Ezine & 11 & 63.45 & & \\
\hline & Gelibolu & 17 & 77.41 & & \\
\hline & Yenice & 10 & 17.30 & & \\
\hline & Total & 124 & & & \\
\hline
\end{tabular}

When the physical activity levels of physical education teachers are investigated according to the variable of gender, it was found that while $24.2 \%$ of female physical education teachers had high levels and $4.8 \%$ had moderate levels, $66.1 \%$ of male physical education teachers had high levels, $4.0 \%$ had moderate levels and $0.8 \%$ had low levels of physical activity (work physical activity; $\mathrm{z}=-0.201$, $\mathrm{p}=0.840$; total physical activity; $\mathrm{z}=-0.030, \mathrm{p}=0.976$ ). The work activity levels $(p>0.05)$ and total activity levels ( $p>0.05$ ) of physical education teachers did not show any significant difference statistically according to the variable of gender. The points related to physical activity levels of female and male teachers were very close.

When the total physical activity levels of physical education teachers are investigated according to the variable of marital status, $72.6 \%$ of married physical education teachers had high levels while $5.6 \%$ had moderate levels of physical activity. For single physical education teachers, $17.7 \%$ had high levels, $3.2 \%$ had moderate levels of physical activity (work physical activity; $\mathrm{z}=-0.406, \mathrm{p}=0.685$; total physical activity; $\mathrm{z}=-0.522, \mathrm{p}=0.602$ ). According to the variable of marital status for the physical 
activity levels of physical education teachers, there was no significant difference between work activity levels ( $p>0.05)$ and total activity levels $(p>0.05)$. Teachers being single or married did not create any difference in physical activity levels.

When the physical activity levels of physical education teachers are investigated from the point of view of age, it was found that for physical education teachers between $21-25$ years $3.2 \%$ had high and $2.4 \%$ had moderate levels, for physical education teachers between $26-30$ years $6.5 \%$ had high and $1.6 \%$ had moderate levels, for physical education teachers between $31-35$ years $14.5 \%$ had high and $0.8 \%$ had moderate levels, for physical education teachers between $36-40$ years $27.4 \%$ had high and $2.4 \%$ had moderate levels and for physical education teachers 41 years and above $38.7 \%$ had high, $1.6 \%$ had moderate and $0.8 \%$ had low levels of physical activity (work physical activity; $x^{2}=2.112, \mathrm{p}=0.715$; total physical activity; $x^{2}=8.285, \mathrm{p}=0.082$ ).

The work activity levels $(\mathrm{p}>0.05)$ and total activity levels $(p>0.05)$ of physical education teachers did not show any difference according to the variable of age. There was no determination of difference in physical activity levels of physical education teachers according to age. The work activity levels $(p>0.05)$ and total activity levels $(p>0.05)$ of physical education teachers did not show any difference according to the variable of length of service.

When the physical activity levels of physical education teachers are investigated according to place of residence, $39.5 \%$ of those living in the center had high physical activity, $25 \%$ of those living in Biga county had high physical activity, $8.1 \%$ of those living in Ezine county had high physical activity, $13.7 \%$ of those living in Gelibolu county had high physical activity and $4 \%$ of those living in Yenice county had high physical activity. The work activity levels $(\mathrm{p}<0.05)$ and total activity levels $(\mathrm{p}<0.05)$ of physical education teachers showed a significant difference according to place of residence. The variable of place of residence was a determinant in differing physical activity levels. According to this result, work activity levels were different for those living in the center and in Yenice. The points for those residing in the center were higher. Total activity levels were different for those living in Gelibolu and the center compared to those living in Biga Yenice; with the total activity levels higher for those living in Gelibolu and the center. Additionally there was a difference in activity levels for those in Yenice compared to Biga and Ezine, with those living in Yenice having lower physical activity levels.

\section{DISCUSSION}

This research was completed with the aim of determining whether the physical activity levels of physical education teachers working in organizations in Canakkale province showed any differences based on gender, age, years of service, marital status and place of residence.

When the physical activity levels of physical education teachers are investigated according to the variable of gender, the physical activity levels of male teachers were higher than female teachers, however this result was found not to be statistically significant. When studies completed about physical activity levels are considered, it can be seen that different results have been obtained about gender. In another study of university preparatory students found there was no difference in physical activity levels of girl and boy students (3). However when intense physical activity levels were investigated there was a statistically significant difference seen between female and male individuals. Physical activity levels were affected by the variable of gender. This effect may be in favor of men or women (7). In a study of university students Öztürk (16) determined there was a difference in total physical activity levels between girls and boys in favor of men. Studies by many researchers had stated that physical activity levels differ according to the variable of gender and this difference is in favor of men $(1,11,15,19)$. Haase et al. (13) in a study of university studies in 23 countries found that men were physically more active and that physical activity levels were higher than for women.

As a result it may not be significant to interpret physical activity levels based on the effect of the gender variable alone. However it is possible to say that the lack of significant difference in physical activity levels due to gender in this study may be caused by the study group being composed of physical education teachers and because physical activity is the basis of their work environment. In addition to this, choice of occupational branch of physical education teachers is separate from other teaching areas, and that those with sufficient ability in this area may be successful in the selection examination. As a result physical education teachers in choosing education before service may be affected 
by sensitivity to physical activity in childhood and youth. When this is considered it can be said that interpreting the differences in physical activity levels of physical education teachers is different to other individuals and that this difference may be sourced in the continuous physical activity habits of physical education teachers since childhood. The participation levels of physical activity in childhood and the teenage period determined that these affected physical activity levels in adulthood (20).

When the physical activity levels of physical education teachers are investigated according to age, as age advances physical activity levels increase; however this increase was found not to cause a statistically significant difference. Similar studies have reached different conclusions. Burton \& Turrell (4) and Cauley et al. (5) revealed a negative relationship between age and physical activity in their studies. Additionally research has emphasized that youngsters are more active than the elderly. Arabacı \& Çankaya (1) found a positive relationship between age and physical activity; they reached the conclusion that older physical education teachers were more active than younger ones. Thus it is seen that results show that the age variable may affect physical activity in a positive or negative way.

When the physical activity levels of physical education teachers are investigated according to the variable of marital status, it was found that being married or single created no difference. When the marital status variable is examined in the study by Arabacı \& Çankaya (1), they determined that married physical education teachers were more active than those who were not married. Hallal et al. (12) reached parallel results in their studies. When the physical activity levels of physical education teachers are investigated according to length of service, as the number of years worked increases, the physical activity levels increase; however this was found not to be statistically significant. This situation is thought to be due to the intense physical activity of the duties performed by physical education teachers, according to seniority the lack of significant difference in physical activity levels was seen to be normal $(10,21,23)$.

Contrary to the other variables there was a difference found in the physical activity levels of physical education teachers according to place of residence. Teachers resident in regions close to the center of Canakkale province or in regions socioeconomically able to contribute to physical education levels were seen to have higher levels of physical activity. When considered from this angle, it is important to consider theoretical infrastructure that supports this result. In societies with high income levels there may be more possibilities to increase physical activity levels. Another research showed that sport was more common and at a more advanced level in countries developed from both a social and economic perspective with high levels of income compared to less developed countries.

Additionally, in a very strong way the environment that people live and work in affects their possibilities to be physically active (6). In conclusion, it is a normal result that the characteristics of the region where the physical education teachers included in the study live affect their physical activity levels. Socio-economic conditions affect physical activity in many ways. It has been shown that participation in physical activity in free time is directly related to socioeconomic situation (6). Physical activity levels are affected by the variable of socio-economic situation (7). There are findings opposite to these stated results. For example, the study by Hallal et al. (12) emphasized the negative relationship between physical activity and socio-economic situation. As the socio-economic situation of individuals improve, the physical activity levels fall. As a result, the variable of socio-economic situation is one that requires attention in terms of how it affects the lifestyles of individuals. It is important to reveal the possibilities for or obstacles to physical activity in the lives of individuals that are due to place of residence. The effect of variables shaping the physical activity levels of physical education teachers may be researched for those working in other occupational branches and the results may be comparatively analyzed. The physical activity levels of physical education teachers may be investigated in regard to some control variables such as teachers' use of cigarettes, frequency of alcohol intake, height, weight, body mass index, media habits and social activities. In terms of the difference caused by place of residence on physical activity levels, conditions affecting living standards should be balanced and the topics of areas or activities that encourage physical activity should be promoted by local authorities to keep physical activity levels high.

In conclusion, this research revealed that the physical activity levels of physical education teachers did not differ according to the variables of 
gender, age, marital status and years of service but did differ according to place of residence. It is seen that there are studies supporting and contradicting this result. A natural consequence of the occupation of physical education teachers is that it is a discipline focused on physical activity. As a result, the effects of a variety of variables may be reflected differently on physical activity levels. When the effects of the variables examined are considered the following recommendations may be made.

\section{REFERENCES}

1. Arabacı R, Çankaya C.Beden eğitimi öğretmenlerinin fiziksel aktivite düzeylerinin araştırılması. Uludağ Ünv. Eğt. Fak. Dergisi, 2007; 1(20): 1-15.

2. Arslan C, Koz M, Gür E, Mendeş B.Üniversite öğretim üyelerinin fiziksel aktivite düzeyleri ve sağlık sorunları arasındaki ilişki. F.Ü. Sağlık Bilimleri Dergisi, 2003; 17(4): 249258.

3. Brown DW, Balluz LS, Heath GW.Associations between recommended levels of physical activity and health-related quality of life. Findings from the 2001 behavioral risk factor surveillance system (BRFSS) survey. Preventive Medicine, 2003; 37: 520-528.

4. Burton NW, Turrell G.Occupation, hour worked and leisuretime physical activity. Preventive Medicine, 2000; 31: 673-681.

5. Cauley JA, Donfield SM, Laporte RE, Warhaftig NE.Physical activity by socioeconomic status in two population based cohorts. Medicine \& Science in Sports \& Exercise, 1991; 23 343-351.

6. Cavill N, Kahlmeier S, Racioppi F.Avrupa'da fiziksel aktivite ve sağlık: eyleme geçirecek kanıtlar (Ter. Türkiye Sağlıklı Kentler Birliği). Dünya Sağlık Örgütü. 2006.

7. Clarke KK, Freeland-Graves J, Klohe-Lehman DM, Milani TJ, Nuss HJ, Laffrey S.Promotion of physical activity in lowincome mothers using pedometers. Journal of the American Dietetic Association, 2007; 107(6): 962-967.

8. Craig CL, Marshall AL, Sjostrom M, Bauman AF, Both ML, Ainswort BE.International physical activity questionnaire: 12country reliability and validity. Medicine \& Science in Sports \& Exercise, 2003; 35: 1381-1395.

9. Erkal M, Güven Ö, Ayan D. Sosyolojik Açıdan Spor. Der Yayınları, Üçüncü Basım. İstanbul, 1998: 150-152.

10. Geçkil E, Yıldız S.Adölesanlara yönelik beslenme ve stresle başetme eğitiminin sağlığı geliştirmeye etkisi. Cumhuriyet
Üniversitesi Hemşirelik Yüksek Okulu Dergisi, 2006; 10(2): 19-28.

11. Genç A, Şener Ü, Karabacak H, Üçok K. Kadın ve erkek genç erişkinler arasında fiziksel aktivite ve yaşam kalitesi farklılıklarının araştırılması. Kocatepe Tıp Dergisi, 2011; 12: 145-150.

12. Hallal PC, Victora CG, Wells JCK, Lima RAC.Physical inactivity: prevalence and associated variables in Brazilian Adults. Medicine \& Science in Sports \& Exercise, 2003; 35(11): 1894-1901.

13. Haase A, Steptoe A, Sallis JF, Wardle J.Leisure-time physical activity in university students from 23 countries: associations with health beliefs, risk awareness, and national economic development. Preventive Medicine, 2004; 39: 182-190.

14. Heyward VH. Advanced Fitness Assessment and Exercise Prescription. 5th ed. USA: Human Kinetics. 2006: 2-11.

15. Karaca A.Yetişkin bireylerde orta ve yüksek şiddetli fiziksel aktivitenin cinsiyete göre incelenmesi. Hacettepe Spor Bilimleri Dergisi, 2008; 19(1), 54-62.

16. Öztürk M. Üniversitede eğitim-öğretim gören öğrencilerde uluslararası fiziksel aktivite anketinin geçerliliği ve güvenirliği ve fiziksel aktivite düzeylerinin belirlenmesi. Yüksek lisans tezi, Hacettepe Üniversitesi, Sağlık Bilimleri Enstitüsü, 2005.

17. Sağlam M, Arikan H, Savci S, Inal-Ince D, Bosnak-Guclu M, Karabulut E, Tokgozoglu L. International physical activity questionnaire: reliability and validity of the Turkish version. Perceptual and Motor Skills, 2010; 111(1): 278-284.

18. Santiago JA, Disch JG, Morales J.Elementary physical education teachers content knowledge of physical activity and health-related fitness. The Physical Educator, 2012; 69: 395-412.

19. Savcı S, Öztürk M, Arıkan H, İnal D, Tokgözoğlu L.Üniversite öğrencilerinin fiziksel aktivite düzeyleri. Türk Kardiyoloji Derneği Arş, 2006; 34: 166-172.

20. Taylor WC, Blair SN, Cummings SS, Wun CC, Malina RM.Childhood and adolescent physical activity patterns ve adult physical activity. Medicine \& Science in Sports \& Exercise, 1999; 31(1): 118-123.

21. Yalçınkaya M, Özer F, Karamanoğlu YA.Sağlık çalışanlarında sağlıklı yaşam biçimi davranışlarının değerlendirilmesi. TSK. Koruyucu Hekimlik Bülteni, 2007; 6(6): 21-34.

22. International Physical Activity Questionnaire (IPAQ). (2005). IPAQ - Scoring Protocol.

23. Zaybak A, Fadıloğlu Ç.Üniversite öğrencilerinin sağlı̆̆1 geliştirme davranışı ve bu davranışı etkileyen etmenlerin belirlenmesi. Ege Üniversitesi Hemşirelik Yüksekokulu Dergisi, 2004; 20(1): 77-95. 